\title{
CORRESPONDENCE
}

\section{CATARACT SURGERY}

To the Editorial Committee of the British Journal of Ophthalmology

SiRS,--My attention has been drawn to an article by Dr. A. Mortada (British Journal of Ophthalmology, 1963, 47, 753), in which he reported very high percentages of shallow anterior chamber and iris prolapse after the use of alpha-chymotrypsin (ACT). In my opinion these complications should not be attributed to the enzyme but may be due to the fact that the surgical technique had not been properly adapted to enzymatic zonulolysis, as I have pointed out in my papers and lately in the book "Surgery of the Anterior Segment of the Eye" (McGraw-Hill, New York). In my statistical studies of cases operated between 1956 and 1961 (2,345 cases, 1,126 without and 1,219 with enzymatic zonulolysis), the following percentages of the above-mentioned complications have been found during 1959, 1960, and 1961:

\begin{tabular}{l|l}
\hline Shallow Anterior Chamber & $2 \cdot 2$ per cent. with ACT \\
& 3.5 per cent. without ACT \\
\hline Iris Prolapse & $0 \cdot 25$ per cent. with ACT \\
& 0.23 per cent. without ACT \\
\hline
\end{tabular}

Apart from the use of alpha-chymotrypsin the surgical technique was identical in all casesrelatively scleral incision, large conjunctival flap, and seven or more corneo-scleral subconjunctival sutures with $8-0$ virgin silk.

INSTITUTO BARRAQUER, Yours faithfully, JOAQUín BARRAQUER, Executive Director. BarCELONA, SpAIN, February 1, 1964.

\section{To the Editorial Committee of the British JouRnal of OpHTHALMOLOGY}

Sirs,-After reading Dr. Aly Mortada's article on cataract technique (Brit. J. Ophthal., 1963, 47, 753), I wish to draw attention to certain points not fully covered. In my paper (Hill and Barraquer, 1961) it was explained in detail how and why the quantity of the enzyme used would affect only the lower portion of the zonule. This was determined by staining the enzyme with fluorescein and tracing its movements.

Also, I believe that recent reports do not substantiate the theory that the enzyme itself causes delayed healing of the wound. Healing depends upon proper wound closure, and in our experience does not differ; with or without use of the enzyme we have had about one per cent. of post-operative shallow chambers. We have had no iris prolapses in the last 400 cases. As to the length of time the enzyme can be left in the eye, I doubt that 2 minutes should be set as an exact time limit. When we occasionally do use ACT, we wait 2 or 3 minutes before irrigating because this length of time seems adequate. Dr. Mortada's record of 10 per cent. delayed wound healing and 9 per cent. iris prolapse when the enzyme is used, seems rather fantastic. If such complications occurred in our hands, we most certainly would not use this method.

Yours faithfully,

33 College Avenue,

HowaRd F. HiLl, M.D.

WATERVILLE, MAINE, U.S.A.

January 23, 1964. 